\section{Derekutuğun Yerleşimi Arkeozoolojik Çalışmaları Işığında Hayvan Kalıntılarının Tartılmasının Önemi}

\author{
* Sorumlu Yazar / Corresponding Author: \\ Can Yümni Gündem \\ Batman Üniversitesi, Fen-Edebiyat Fakültesi \\ Arkeoloji Bölümü, Tarih Öncesi Arkeolojisi Anabilim Dalı \\ Batı Raman Kampüsü, Oda: 76 \\ 72100 Batman/TÜRKIYE \\ E-posta: canyumni@hotmail.com
}

\section{Can Yümni GÜNDEM ${ }^{1 *}$}

${ }^{1}$ D. Öğr. Üyesi, Batman Üniversitesi, Tarih Öncesi Arkeolojisi Anabilim Dalı, Batman/TÜRKiYE Öz

Bu çalışmanın iki ayrı konu başlığı bulunmaktadır. İlk olarak Arkeozoolojik çalışmalarda hayvan kalıntılarının neden tartılması gerektiği tartışılmış, ikinci olarak ise bu metodun önemini gösterebilmek için Prof. Dr. Ünsal Yalçın'ın kazı başkanlığında yürütülmüş Derekutuğun Madenci Yerleşimi'nin Arkeozoolojik çalışmalarından örnek verilmiştir. Bu araştırma yalnızca Derekutuğun Yerleşimi'nden çıkarılan İlk Tunç Çağ III (İTC III) katmanlarına ait havvan kemiklerinin incelenmesi üzerinedir. Çorum İl sınırları içinde yer alan Derekutuğun bir madenci yerleşimi olup, yakında bulunan bakır cevherinin günümüzden 4.000 sene önce madenciler tarafından çıkarılıp sonra işlendiği bir yerdir. Bakır cevheri çıkarmak ve işlenmesi için kurulmuş olan bu yerleşimde yaşamış insanların kırmızı et tüketme alışkanlıklarını anlamak aslında Anadolu arkeolojisi için bir ilk olmuştur. Madenciler kırmızı et ihtiyaçlarını eşit ağırlıkta sı̆̆ır ve domuzdan tedarik ederken, koyun üçüncü sıradadır. Bu sonuçlar yakındaki Derekutuğun'nun çağdaşı olan Boğazköy yerleşimindeki hayvan bağlı ekonomisi ile çok keskin zıtlıklar göstermektedir.

Anahtar Sözcükler: Arkeozooloji, Derekutuğun, hayvan kemiği, arkeozoolojide tartı yöntemi, geçim ekonomisi, madenci diyeti

\section{Giriş}

$\mathrm{Bu}$ çalışmanın iki ana konu başlığ bulunmaktadır. Birincisi, antik toplumların kırmızı et tüketimlerini sağliklı olarak hesaplayabilmek ve anlayabilmek için neden hayvan kemik kalıntılarının ağırlıklarının alınmasının gerekliliğinin tanıtılması $-\mathrm{ki}$ bu Arkeozooloji biliminin en önemli yöntemlerinden biridir), ikincisi ise Derekutuğun Madenci Yerleşimi'nden çalışlan hayvan kemik kalıntıları verilerinin örnek olarak yerleşim dâhilinde ve komşu yerleşim Boğazköy ile karşıllaştırlmasıdır.

Derekutuğun Madenci Yerleşimi Anadolu madencilik tarihinin anlaşılması açısından anahtar yerleșim verlerinden biridir. Maden ocaklarından çıkarılan bakır cevheri, ocaklara çok yakın yerde kurulmuş olan madenci kasabasında işlenmiștir. Bu kasaba yalnızca cevherin ișlendiği yer değil, aynı zamanda da madencilerin yaşam alanıdır.

Derekutuğun Madenci Yerleşimi Kazısı'ndan
Alınd/Received: 7 Ekim / October 2019 Düzeltildi/Revised: 13 Aralık / December 2019 Kabul/Accepted: 17 Aralık / December 2019 Yayımlandı/Published: 20 Aralık / December 2019
The Importance of Weighing Faunal Remains in the Light of Archaeozoological Research of Derekutuğun Settlement Abstract

There are two main topics of this study. One is the importance of weighing the animal bones for the archaeozoological studies, and the other one is, in order to demonstrate the importance of this method, the study on archaeozoological material from the Derekutuğun Miner Settlement excavation directed by Prof. Dr. Ü. Yalçn. This research discusses only the examination of the animal bones from the Early Bronze Age III (EBA III) levels of the Derekutuğun Settlement. Derekutuğun, located within the borders of Corum Province, was a former miner settlement and is a place where the nearby copper ore was extracted and processed by these miners 4,000 years ago. Understanding the habits of red meat consumption of the people who lived in this settlement, which was established intentionally for extracting and processing copper ore, is the first time for the Anatolian Archaeology. Miners supply their red meat demands from cattles and pigs of equal weight, while the sheep was their third choice. These results show sharp contrasts with the animal-based economy of Boğazköy, which is contemporary and very close to Derekutuğun.

Key Words: Archaeozoology, Derekutuğun, animal bones, weighing method in archaeozoology, prehistorical animal based economy, miner's diet

çıkarılan ve Tunç Çağlarına tarihlenen hayvan kemikleri Çorum Müzesi’nde, çalışmanın yazarı ve onun gözetiminde S. Sarı, E. Emlük ve E. Gündem tarafindan incelenmiştir. Çalış̧manın sonuçları daha sonra S. Sarr'nın yüksek lisans tezinin de temelini oluşturmuştur.

Arkeozoolojik çalışmaların ne olduklarını ve neden yapıldıklarının temel sebeplerini kısaca şu şekilde özetleyebiliriz: "Arkeozooloji; arkeolojik kazılardan çıkarllan hayvan kalıntılarından yola çıkarak, insanlar ile hayvanların en eskiye dayanan ilisskilerinden günümüze olan gelişimini, değişimini, birbirlerine ve doğaya olan olası etkilerini/etkileşimlerini belli bir kronolojiye bağlı kalarak araştıran ve bu araştırmaları bilim dünyasında kabul görmüş temel metotlar dâhilinde inceleyen bilim dalıdır." (Gündem, 2015).

Bu çalışmada ise Arkeozooloji biliminde hayvan kemiği kalıntllarının ağırlıklarının alınmasının önemini göstermek için Derekutuğun Madenci Yerleşimi’nin 


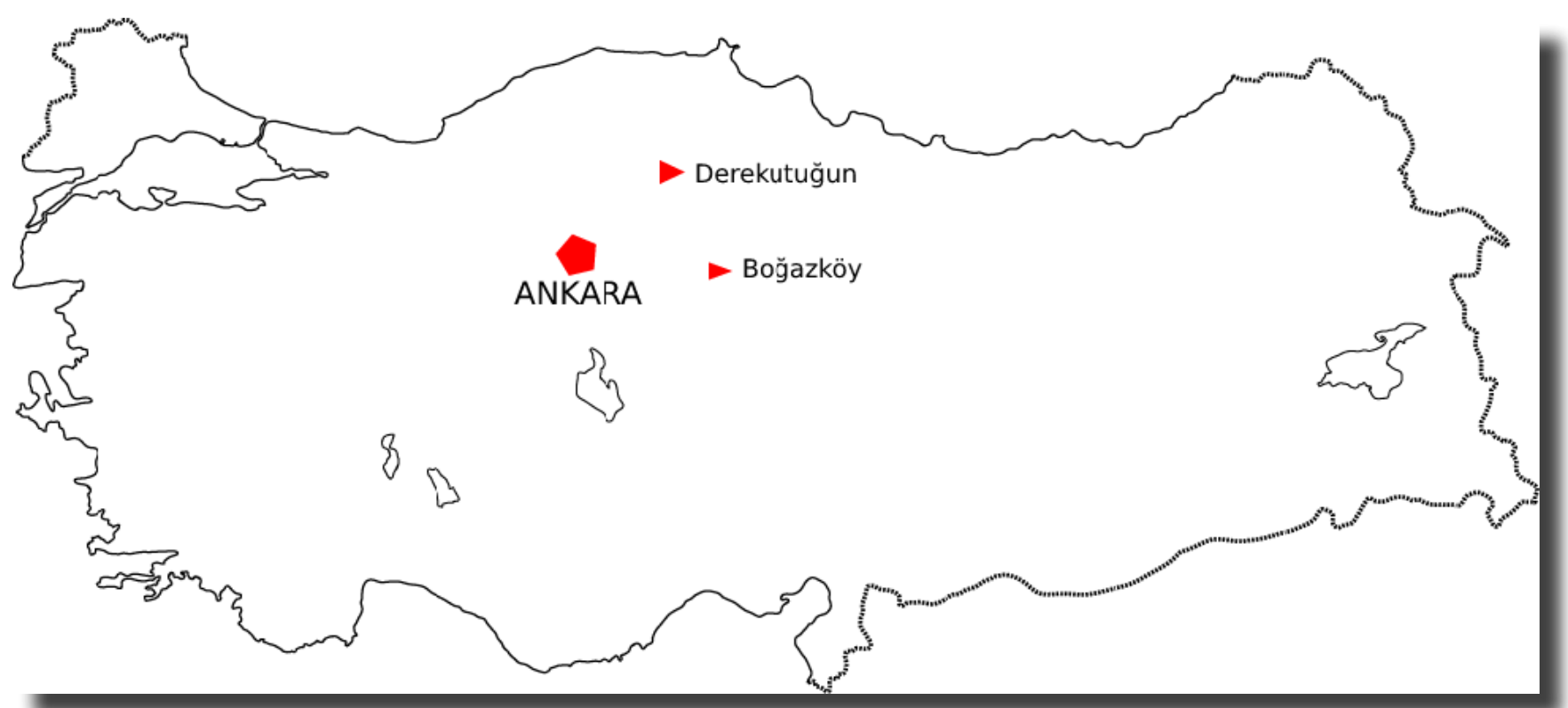

Resim 1. Derekutuğun Madenci Yerleşimi ve Boğazköy Yerleşimi’nin Türkiye haritasındaki yerleri

yalnızca İTÇ III Dönemi'nden çıkarılan faunal malzemelerinin kullanılmış ve Derekutuğun Madenci Yerleşimi ile Boğazköy arasında karşılaştırmalara ağıllık verilip, iki yerleşmedeki hayvan ekonomisinde görülen farklılıklar ile olası sebepleri burada farklı tezler ışığında tartışılmışıtır.

$\mathrm{Bu}$ çalışmanın diğer bir amacı ve belki de en önemlisi, ülkemizde sayısı artmakta olan Arkeozoolog adaylarına kemik ağırlıklarının tartılmasının önemini örneklemeli bir çalışma ile anlatmaktadır.

\section{Derekutuğun Yerleşiminin Genel Arkeolojisi}

Derekutuğun Maden İşletmeciliği'nin adını aldığ1 Derekutuğun Köyü, Çorum İli, Bayat İlçesinin batısında yer almaktadır. Köroğlu Dağları'nın güney ucunda bulunan Derekutuğun Köyü, tepeli ve engebeli yapıda bir araziye sahiptir ve Kızılırmak'in yaklaşık $20 \mathrm{~km}$ kuzeyinde yer almaktadır (Yalçın vd., 2015) (Resim 1). Derekutuğun Yerleşimi, adını aldığ1 köyün doğusunda bulunan Erikli ve Mazıönü mevkileriyle ön plana çıkmaktadır. Yüzey araştırmalarının sonuçları bölgede zengin nabit bakır yataklarının bulunduğunu göstermiştir. (Yalçın ve İpek, 2011). Derekutuğun'dan çıarılan bakırın saflık derecesinin yüksek olmasından dolayı Tunç Çağı'nda tercih edilen hammadde olduğu düşünülmektedir (Yalçın vd., 2015).

Heidelbergli bir grup bilim insan1 1980 senesinde Derekutuğunveçevresindekısa sürelibiryüzeyaraştırmas1 yapmıştır. O dönemde yapılan bu araştırmalarda antik madencilikle ilgili herhangi bir buluntu grubuna ulaşılmamıştır. Söz konusu durum Prof. Dr. Ünsal Yalçın ve ekibinin, Derekutuğun Madenci Yerleşimi'nde 2008 yılında yaptığı yüzey araştırmasında elde edilen bulgular neticesinde, burada maden işletme izlerinin bulunması ile farklılık göstermiştir (Yalçın vd., 2015). Yerleşimde ilk kazı çalışmaları Prof. Dr. Ünsal Yalçın'ın bilimsel danışmanlığında 2009-2012 yılları arasında yapılmıştır (Yalçın ve İpek, 2012). Alman Araştırma Kurumu'ndan (DFG, Deutsche Forschungsgemeinschaft) ödenek sağlanarak 2015 - 2017 yılında arasında tekrar kazılar yapılmış ve bu dönemleri kapsayan kazı sezonlarında Erikli Mevkii kazılmışır (Yalçın vd., 2018).

Yapılan çalışmalar kapsamındaki dönemsel tarihlendirmeler, açmalardan elde edilen çanak-çömlek/ seramik parçaları ve küçük buluntular üzerinden yapılmıştır (Yalçın vd., 2015). Yerleşimden tespit edilmiş çanak-çömlek, Derekutuğun yerleşiminin ilk tabakalarını Kalkolitik Çağ’a tarihlemiştir. Derekutuğun Erikli Mevkii'nde yapılan çalışmalar ise bize höyüğün iskân kronolojisini en üstten alta doğru şu şekilde vermektedir: Roma Dönemi, Hellenistik Dönem, Demir çağı, Hiatus, Karum (Asur Ticaret Kolonileri Çağı) Dönemi, İTÇ III'ten OTÇ III'e Geçiş Dönemi, ITTÇ III, İTÇ II, İTÇ I ve Kalkolitik Dönemi (Yalçın vd., 2018).

\section{Gereç ve Yöntem}

Giriş kısmında da kısaca belirtildiği gibi bu çalışmanın amac1 Derekutuğun Yerleşimi'nin genel İTÇ III döneminde yaşamış olan madencilerin kırmızı et tüketim alışkanlıklarını anlamak ve bunu anlayabilmek için de yapılması gereken en temel metotlardan birini tanıtmaktır: hayvan kemiklerinin tanımlama sırasında tartılması. Bu çalışma için yalnızca İTÇ III döneminden tanımlanan hayvan kemiklerinin verileri kullanılmıştır. Toplamda 1172 adet hayvan kemiği veri bankasına girilmiştir ve bu malzeme grubu yaklaşık 15,1 kg'a denk gelmektedir (Tablo 1). 
Tablo 1. Derekutuğun Madenci Yerleşimi'nin İlk Tunç Çağı III tabakasından çalışılmış memeli hayvan kalıntılarının adet ve ağırlık olarak yüzdelik dağılımı

\begin{tabular}{rcc}
\hline Derekutuğun İTÇ III & Adet (\%) & Ağırlık (\%) \\
\hline Orta boy memeli & 81,7 & 49,3 \\
Orta - büyük boy memeli & 16,5 & 42,3 \\
Büyük boy memeli & 1,8 & 8,4 \\
Tanımlanamayan & $\mathbf{1 0 0}$ & $\mathbf{1 0 0}$
\end{tabular}

$\begin{array}{rcc}\text { Köpek } & 0,6 & 0,2 \\ \text { Koyun } & 43,5 & 25,0 \\ \text { Keçi } & 6,8 & 7,2 \\ \text { Domuz } & 30,8 & 31,9 \\ \text { Sığır } & 16,1 & 31,9 \\ \text { Eşek/Katır } & 1,0 & 2,7 \\ \text { van Faunası } & \mathbf{9 8 , 8} & \mathbf{9 8 , 9}\end{array}$
(adet: 774 , ağırlık: $13212 \mathrm{gr}$ ) 98,8 98,9

$\begin{array}{rll}\text { Alageyik } & 0,1 & 0,2 \\ \text { Karaca } & 0,1 & 0,1 \\ \text { Geyik (türleri) } & 0,3 & 0,2 \\ \text { Tilki } & 0,5 & 0,4 \\ \text { Etçil (?) } & 0,1 & 0,2 \\ \text { Tavşan } & 0,1 & 0,0 \\ \text { ağıan Faunası } & \mathbf{1 , 2} & \mathbf{1 , 1}\end{array}$

Yabanî Hayvan Faunası
(adet: 10, ağırlık: $133 \mathrm{gr}$ ) 1,2 1,1

\begin{tabular}{rcc} 
Tanımlanamayan & 33,5 & 11,6 \\
Tanımlanan & 66,5 & 88,4 \\
Toplam & 100 & 100 \\
\hline
\end{tabular}

Bu malzeme "Görsel tanımlama metotları" 1şı̆̆ında incelenmiş ve veri bankasına girilmiştir. $\mathrm{Bu}$ genel metotlar sırasıyla şöyledir: kazıdan çıkan ve incelenen her bir hayvan kemik parçasının önce taksonomik sonra anatomik olarak tanımlanması, oluşmuş parçalanma derecesinin tespiti, kemiklerinüzerindeki kasaplık-yanma izlerinin varlığ1 ve insanlar tarafindan oluşturulmuş diğer modifikasyon verilerinin kaydedilebileceği bir Microsoft ${ }^{\circledR}$ Excel temel veribankasina girilmesi (Schmid, 1972; Hillson, 1992; Fisher, 1995; O’Connor, 2000; Reitz ve Wing, 2008; Peres, 2010). Dijital terazi yardım1 ile incelenen her bir hayvan kemik kalıntıs1, ağırlı̆g alındıktan sonra veribankasına girilmiştir; çünkü hayvan kemiğinin ağırlığ 1 ile kemiğin taşıdığ1 et orantılıdır. Bu da bize et tüketimi hakkında en önemli bilgiyi vermektedir

\footnotetext{
${ }^{1}$ Yazar bu terimi 2011 senesinde Brüksel'de toplanan ASWA konferansında kullanmış ve daha sonra 2015 senesinde "Arkeozooloji Biliminin Arkeoloji Dünyasındaki Önemi Bölüm I" adlı makalesinde de (2015) yazılı olarak tanıtmıştır. "Görsel tanımlama metotları" aslında Arkeozooloji biliminde kullanılan klasik metotların bir başlık altında toplanmasıdır (Gündem, 2015).
}

(Kubasiewicz, 1956; Uerpmann, 1973). Bu veriler dışında hayvanların kesim yaşı hakkındaki bilgiler, hem dişlerin yıpranma hem de eklem kaynama verilerine dayanarak toplanmış ve kaydedilmiştir. Bu toplanan bilgiler bize hayvancılık yönetiminin hedefleri hakkında fikirler verir (Uerpmann, 1971, 1973; Payne 1973; Hillson 1986). Hayvan kemiklerinin ölçülmesi ise onların fiziksel gelişimlerine ilişkin açıklamalar yapılmasını sağlar. Kemiklerin ölçümleri için kullanılan yöntembilimi A. von den Driesch tarafindan kitap olarak yayımlanmıştır (von den Driesch 1976; Uerpmann 1979; Meadow, 1999).

$\mathrm{Bu}$ çalışma için tanımlanan türlerin özellikle malzeme grubu içinde dağılımları ve kemiklerin ağırlık verileri birlikte kullanılmıştır. Kemik ağırlı̆g ile kemiğin taşıdığ1 et orantılıdır. Bu nedenle, yapılan arkeozoolojik çalışmalardan net sonuçlar elde edilebilmesi için veri bankasına girilen her hayvan kemiğinin, aynı zamanda ağırlığının da alınması gerekmektedir (Uerpmann, 1973; bkz. Gündem, 2010, 2015).

Bir koyunun ve sığırın iskeletinde bulunan kemik sayısı aynı olsa da, koyun ile sığır arasındaki hacim farkı kesindir. Bir koyunun üst bacak kemiği ile bir sığırın üst bacak kemiği aynı miktarda et taşıyamaz. Başka bir ifadeyle her iki hayvanın taşıdığ1 et, kemik boyutu ve kemik ağırlı̆̆1 ile doğru orantılıdır. Uerpmann, hayvan kemik ağırlıklarının alınmasının önemini Kubasiewicz’in 1956 yılındaki çalışmasından yola çıkarak açıklamışıı (Uerpmann, 1973).

Hayvan kemiklerinin adedi bir nicelik ise, işte o sayımlara nitelik kazandıracak kavram onların tartılmasıdır (Uerpmann, 1973). Sayılan ve tür bazında gruplanan hayvan kemikleri, et kazanımının türü bazında yerleşim yeri sakinlerinin tercihleri hakkında bilgi verir. Türlere ayrilmış hayvan grupları et tüketimi hakkında ancak kabataslak fikir verirler; bu fikirler ister istemez bilim insanlarını veya okuyucuları yanlış yönlendirebilir.

Bunun sebeplerinden birincisi, bir koyunun ve sığırın iskeleti aynı sayıda kemikten oluşması ama bu hayvanların arasında gözle görülür bir cüsse/ağırlık farkının varlığıdır. Koyunun ve sı̆̆ırın taşıdığı et miktarı her birinin kendi kemiklerinin iriliği ve ağırllğı ile orantılıdır. İkicisi sebep ise, kazıda çıan koyun üst bacak kemiği parçasının da, sığı üst bacak kemiği parçasının da birer adet olarak sayılmasıdır. Unutulmamalıdır ki kazılardan çıkan herhangi bir türe ait "tam" üst bacak kemiği onlarca parçaya ayrılabilir ve genelde de ayrılmış olarak bulunur. Hayvan kemik adetleri üzerinden yapilacak yorumlamaların yetersiz kalma ihtimalinin yüksek olduğu yerlerde, bunun sağlaması ancak parçalanma veya kırılma miktarının önemli olmadığı ama ağırlıklarının temel alındığı bir çalışma ile engellenebilir.

Hem dönemsel hem de bölgesel bir mukayese yapmak için Derekutuğun'un İTÇ III Dönemi'nden 


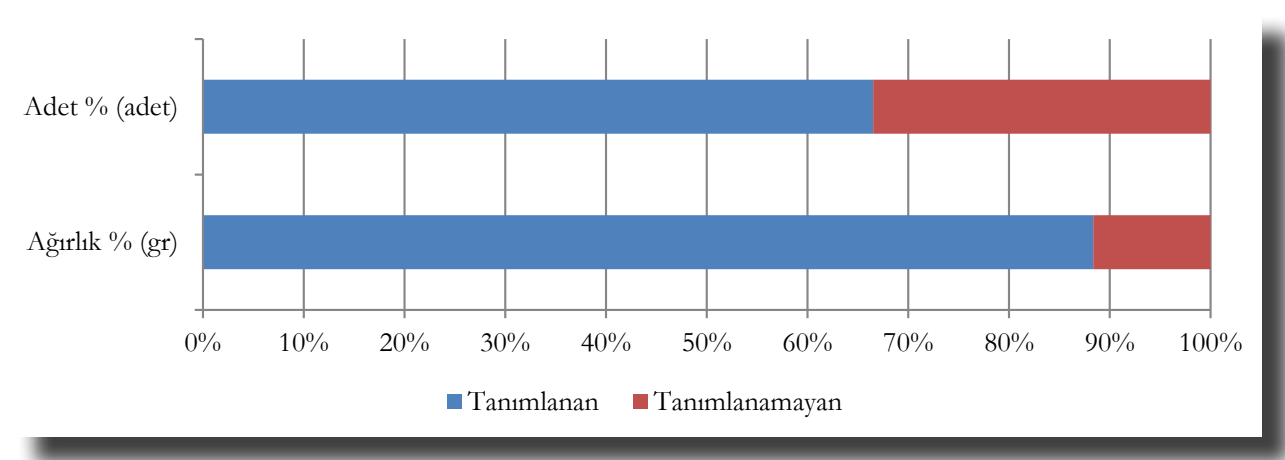

Şekil 1. İTÇ III Dönemi’nden çalıșılmış tanımlanan ve tanımlanamayan memeli hayvan kalıntılarının kendi içinde dağılımı

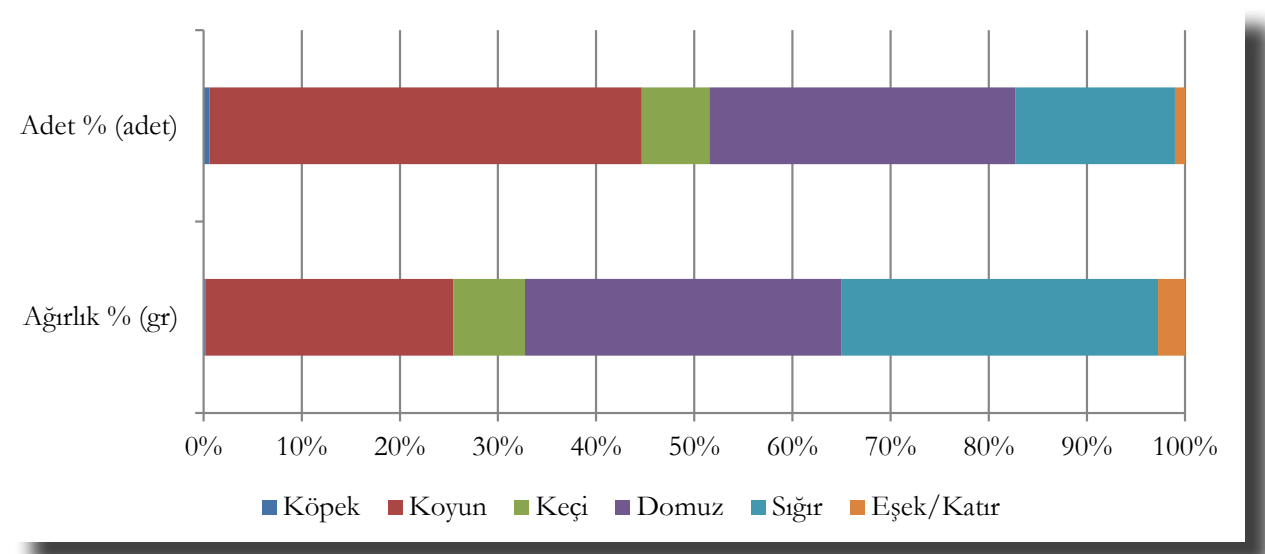

Şekil 2. ITTÇ-III Döneminden çalışılmış evcil memeli hayvan kalıntılarının kendi içinde kesin koyun kalıntılarının kesin keçi oranlarının tekrardan hesaplandıktan sonraki adet ve ağırlıklarının yüzdelik dağılımı

elde edilen tür dağılımı ve kırmızı et kazanımı verileri, Boğazköy'ün İTÇ III tabakasının arkeozoolojik verileri ile karşılaştırılmıştır (von den Driesch ve Pöllath, 2004).

\section{Bulgular}

\section{Derekutuğun Yerleşimi'nin iTÇ III Dönemi'nin Arkeozoolojik Çalışmalarına Genel Bakış}

Derekutuğun hayvan kemiği malzemesinin yaklaşık \%70’i tür bazında tanımlanırken, \%30 kadarı yeterli ayırt edici kriter bulunmadığ1 için tür bazında tanımlanamamıştır. Her ne kadar örneklemin \%30’u tanımlanamamış olsa bile, bu genel malzeme ağırlı̆ıının yalnızca \%10'una denk gelir. Bu da bize tanımlanamayan malzemenin çok küçük kırıklar boyutunda olduğunu ve kazı alanında arkeologların hayvan kemiklerini, boyutları göz önünde bulundurulmadan, dikkatli bir şekilde topladığını gösterir (Şekil 1).

Türlerine ayrilabilen malzeme grubunun hemen hepsi evcil hayvanlardan gelmekteyken (774 adet), yalnızca çok küçük bir hayvan kemiği grubu yabanî hayvan olarak tanımlanmıştır (10 adet). Bu adetler arasındaki büyük sayı farkı aynı zamanda da ağırlık kolonunu da doğrudan etkilemektedir ve yabanî hayvanların kemikleri, tanımlanan genelin yalnızca \%1'ine denk gelmektedir (Tablo 1).

Köpek, koyun, keçi, domuz ve sığır olarak tanımlanan evcil hayvan faunası aslında Anadolu'da görülen İlk Tunç Çağ1 yerleşim yerlerinde görülen tipik evcil hayvan faunasını yansıtmaktadır; ama bunun dışında burada göze çarpan farklılık, az sayıda olsa da, eşek/katır kalıntılarının malzeme grubunda yerini bulmuş olmasıdır. Yabanî hayvan kemiklerine malzeme içinde çok az sayıda rastlanmıştır ve bunlar tavşan, tilki ve geyik türlerine aittir (Tablo 1).

Derekutuğun'da evcil hayvan kalıntılarına bakıldığında toplamda, evcil küçükbaş geviş getiren hayvanların (koyun ve keçi) kesinlikle diğer evcil türlere göre çok daha fazla tanımlandığı görülmektedir. Koyun ve keçi kemiklerini birbirlerinden ayırt etmek için gerekli olan eklem yerlerinin kazılarda nadir bulunmasindan ve evcil küçükbaş geviş getirenlerin kemiklerinin de birbirine boyut olarak çok benzemesinden dolayı bu iskelet elementleri ayr1 ve "suni” bir tür kategorisi olan koyun/keçi (Ovis/Capra) ad1 altında toplanmaktadır. Koyun ve keçi besiciliği amacıyla sağlıklı yaklaşımlarda bulunmak ve yerleşim yerinde tutulan evcil hayvan sürüleri içerisindeki yüzdelerini daha gerçekçi ortaya koyabilmek için kesin olarak tanımlanmış olan koyun ve keçi iskelet elementlerinin birbirine olan oranları temel alınmalıdır (bkz. Gündem, 2010). Koyun veya keçi türlerine kesin olarak ayrılmış kemik oranlarından yola çıkıldığında adet olarak koyun kemiklerinin keçiye oranın $\sim 6,5 / 1$ ve ağırlık olarak da $\sim 3,5 / 1$ olduğu hesaplanmıştır (Şekil 2). 


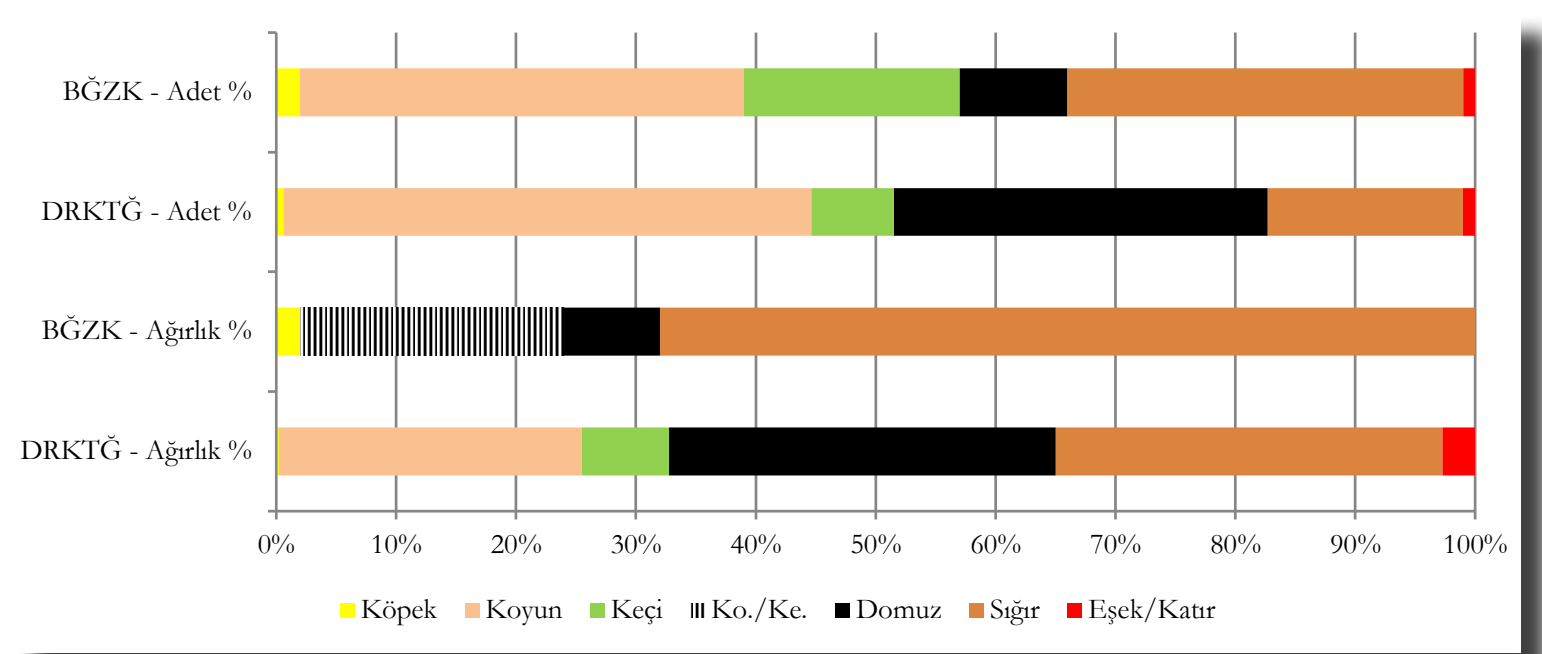

Şekil 3. Adet bazında Boğazköy'den tanımlanmış kesin koyun ve kesin keçi kalıntılarının orantılarından yola çıkarak tekrardan hesaplanan tanımlanmış Boğazköy İTÇ III evcil hayvan faunası dağılımı ve aynı zamanda da ağırlıklarının Derekutuğun Yerleşimi İTÇ III sonuçları ile karşılaştırılması*

Belirtilen bu koyun ve keçi oranlarından yola çıkarak tekrard hesaplanan sürü dağılımına göre, tanımlanan evcil hayvan kemiklerinin \%45'i koyun kemiklerine aittir ve keçi kalıntıları ile evcil küçükbaş geviş getirenlerin kemik kalıntıları genel evcil hayvan malzemesinin $\% 50$ 'sine denk gelir. Koyun kalıntılarını \%30 ile domuz ve yaklaşı \%15 ile sığır kalıntıları takip eder. Keçi kalıntılarını, çok az sayıda tanımlanmış olan eşek/katır kalıntıları izlemektedir (Şekil 2).

Koyun, kalıntıları en çok tanımlanan evcil tür olsa bile, koyun kemikleri evcil hayvan kalıntı ağırlıklarının yalnızca \%25'ini oluşturmaktadır. Domuz ve sığır kemikleri adet olarak çok farklılık gösterse dahi, evcil hayvan kemiklerinin genel ağırlığının \%32'sine denk gelmektedir. Domuz ve sığır kalıntılarının ağırlıklarını koyun ve onu da yaklaşık $\% 7$ ile keçi ve $\sim \% 3$ ile eşek/ katır kalıntıları takip etmektedir.

\section{Derekutuğun Madenci Yerleşiminin iTÇ-III Sakinlerinin Kırmızı Et Kazanım Ekonomisine Genel Bir Bakış}

Hayvan kemiklerinin üzerinde tespit edilmiş kasaplık izleri, bize bu buluntu grubunun mutfak kalıntıs1 olduğunu göstermektedir. Hem evcil hem de yabanî hayvan kalıntıları memeli hayvan kalıntıları içinde tespit edilmiştir ama yabanî hayvan kalıntılarının toplamı tanımlanmış faunanın yalnızca \%1'ine denk gelmektedir. Yabanî hayvan kalıntılarının tanımlanabilen genel fauna içinde bu kadar az bulunması, bize ilk olarak bu yerleşim yerinde yaşayan insanların doğa bağımllıklarının en aza indiğini göstermektedir. Madencilerin kırmız et ihtiyac1 yoğun olarak evcil hayvanlardan karşlanırken, avcilık çok nadir et ihtiyac için gerçekleşen bir aktivitedir.

Yerleşim yerinde en çok beslenen hayvan koyundur ve onu domuz ile sığır takip eder. Keçi ve özellikle eşek/ katır çok küçük gruplar hâlinde yerleşimde tutulmuştur. Bahsedilen hayvanlardan özellikle evcil geviş getirenler ve eşek/ katır², ikincil ürünleri (süt, yün, yük taşıma vb.) için de beslenmiştir ama bu çalışmanın merkezinde yerleşim yeri sakinlerinin et tüketimi yer almaktadır. Unutmamak gerekir ki evcil hayvanlar hastaliktan ölmedikçe büyük bir ihtimalle her hâlükârda menüde yerlerini almaktayd.

Tanımlanan evcil hayvanlara ait iskelet elementleri, tanımlanmış evcil türler bazında incelendiği zaman (kafa, ön kol ve diğer iskelet bölgeleri), kafaya ait parçalar (diş, çene, kafa parçaları, vb.) olarak tanımlanan hayvan kemiği malzemesi içinde yoğun olarak bulunmuştur. $\mathrm{Bu}$ öncül tespit bize bu hayvanların yerleşim yerinde beslendiklerini ispatlamasa bile, hayvanların en azından yerleşime getirilip kesildiklerini göstermektedir.

Koyunlar her ne kadar en büyük sürüyü oluştursa ve tanımlanan domuz kemikleri sığırların iki katı olsa da tartılan kemik ağırlıkları bize yerleşimde ortaklaşa en çok domuz ve sığır etinin tüketildiğini göstermektedir. Madenciler kırmız et ihtiyacının 2/3'sini domuz ve sığır etinden eşit şekilde karşılarken, koyun eti tüm kırmızı et ihtiyacının 1/4'ini karşılamaktadır.

Domuzlar evcilleştirme sürecinin başından beri insanların et ihtiyacını karşılamak için beslenen bir tür olmuştur. Bunun sebebi domuzun biyolojik yapisından kaynaklanır. Domuzlar erken olgunlaşırlar, hızlı kilo alırlar, yem seçmezler ve bir kerede birçok yavru doğurma özellikleri vardır (bkz. Gündem, 2010). Domuzların eklem kaynaşma yaşlandırmasından

\footnotetext{
${ }^{2} \mathrm{Bu}$ döneme ait çalıșılmış hayvan kemikleri içindeki eșek/katır kemik kalıntılarında herhangi bir kasaplık izlerine rastlanmamıştır.
}

* Boğazköy yayınında kesin tanımlanmış koyun/keçi ağırlıkları tek bir veri olarak verilmiștir. 
yola çıkarak elde edilen ilk sonuçlar, domuzların yoğun olarak genç yaşlarda kesilmeye başlandığını ve bunun azalarak yaklaşık üç yaşlarına kadar sürdüğünü göstermektedir. Domuz sürülerinde yaşlı bireylere neredeyse rastlanmamaktadır.

Sı ğırlar senede bir kere yavrulayabilirler ve sığırların olgunlaşması yaklaşık 1,5 sene sürer (bkz. Gündem, 2010). Sığırlar domuzlardan daha az sayıda tutulmasina rağmen, çok daha iri bu evcil hayvanlar madenciler için domuzlar kadar önemli bir et kaynağı olmuşlardır. Senede bir yavrulayan bu türün bir üyesinin kesimi bile büyük bir ihtimalle çiftçiler tarafindan dikkati hesaplamalar ile yapılmaktaydı. Elimizde sığırların cinsiyeti hakkında yeterli veri olmasa bile, büyük olasılıkla inekler sürünün devamlılı̆ıını sağlamak için daha uzun seneler beslenirken, erkek buzağ1 ve danalar et kazanımı ve yem tüketimini azaltmak için daha erken yaşlarında kesiliyorlardı.

\section{Derekutuğun Madenci Yerleşiminin iTç-III Sakinlerinin Kırmızı Et Kazanım Ekonomisine Genel Bir Bakış}

Boğazköy kazısından çıan hayvan kemik malzemesi A. von den Driesch ve N. Pöllath tarafindan incelenip yayımlanmıştır (von den Driesch ve Pöllath, 2004). Bu çalışmada Derekutuğun İTÇ III ve Boğazköy ITTÇ III dönemine tarihlenen hayvan kemiklerinin analiz sonuçları, hem tür hem de özellikle et tüketimi bazında sürü oluşumlarını daha iyi anlayabilmek için karşılaştırılmıştır ${ }^{3}$.

Aynı dönemlere tarihlenen ve aralarında yaklaşık $100 \mathrm{~km}$ olan bu iki yerleşim birbirinden çok farklı iki evcil hayvan ekonomisi sergilemektedir. İlk bakışta her iki yerleşimde de evcil küçükbaş geviş getiren türler kesinlikle çiftçiler tarafindan en çok beslenen türlerdir. Koyun sürüleri Derekutuğun'un nerdeyse \%45'ini oluştururken, Boğazköy'de bu rakam \%40'lar civarındadır; ama keçilerin Boğazköy'de ( \%18) Derekutuğun'a $(\sim \% 6)$ göre üç kat daha çok tercih edildiği gözlenmektedir (Şekil 3).

Anadolu'da İTÇ’de evcil sürülerin diğer demirbaşları sayılan sığır ve domuzların yerleşim yerlerindeki sayıları kesinlikle birbirinden çok farklıdır. Domuzlar Boğazköy'de evcil hayvanların yalnızca yaklaşık \%8'ini meydana getirirken, bu oran Derekutuğun'da \%30’lara çıkmaktadır. Sı̆̆ırda ise buna ters bir oluşum gözlenmektedir. Derekutuğun'da sığırlar genel evcil hayvanların \%16'sına yakınını oluştururken, bu oran Boğazköy'de \%30’ların üstündedir. Boğazköy'deki atgillere ait kalıntılar eşek olarak tanımlanırken,

\footnotetext{
3 Boğazköy'de de İTÇ III'e tarihlenen yabanî memeli hayvan kalıntıları çok az sayıdadır. Dört adet kalıntı genelin \%1,1'ine denk gelir, bu da ağırlığın genelinin \%1,4’ü olarak hesaplanmıştır.
}

Derekutuğun malzemesi șimdilik eșek/katır olarak tanımlanmıştır ve her iki yerleşimde de çok az düzeyde kalıntılarına rastlanmıştır. Köpek kalıntıları ise her iki yerleşimde de \%2'den az olarak tanımlanmıştır.

Evcil hayvan türleri bazında sürüler içindeki dağılımları nasıl farklılık gösteriyorsa, bu farklılık kemik ağırlıklarında da gözlenmektedir. Boğazköy'de sığır, evcil tanımlanmış türler içinde ağırlı̆̆ın yaklaşık \%70’lerine denk gelirken, Derekutuğun'da bunun yarısını oluşturmaktadır. Derekutuğun'da türler arasındaki ağırlık dağılımında kesinlikle homojen bir tablo karşımıza çıkmaktadır. Eşek/katır kalıntılarının ağırlıkları yaklaşık \%3 iken, evcil küçükbaş geviş getirenler ve diğerleri genelin \%30'unun az üstünde hesaplanmıştır. İkinci en belirgin fark domuz kemik ağırlıklarında gözlenmiştir; Derekutuğun'da tartılan domuz kalıntıları Boğazköy'de tartılmış domuzların dört katına denk gelmektedir.

\section{Tartışma ve Sonuç}

Elde edilmiş sonuçlara geçmeden burada arkeozoolojik çalışmalarda hayvan kemik kalıntılarının ağırlıklarının alınmasının (tanımlanabilir veya tanımlanamaz, hepsinin) ve veribankasina girilmesinin sonuçlar ve yorumlamalar için tekrardan ne kadar önemli olduğunu vurgulamak gerekmektedir. Arkeozoolojik araştırmalarda ağırlıkları alınmamış çalışmalar yarım kalmış çalışmalardır. Geçmiş toplumların besicilik faaliyetlerini anlayabilmek ve et tüketimlerine sağlıklı cevaplar bulmak için, hayvan kemiklerinin hepsinin teker teker ağırlıkları alınmalıdır. Derekutuğun'da da görüldüğü gibi, koyun adet olarak domuzdan daha fazla sayıda bulunuyor olsa dahi, ağırlıklarına bakınca domuzun yerleşim yerine et katkısının daha fazla olduğunu görmekteyiz.

Belki de sonuç kısmında en başta belirtilmesi gereken, bu iki İTÇ yerleşiminin -Derekutuğun ve Boğazköy’ün- kırmız et ihtiyacının karşılanması için artık insanların doğaya olan bağımlllkklarının nerdeyse $\% 1$ 'lere inmiş olmasıdır. Bu da bize yerleşimde 100 kilo tüketilen etin yalnızca 1 kilosunun yabanî hayvanlardan geldiğini gösterir. Bu sonuç, iki yerleşim yerinde yaşayan insan topluluklarının hayatta kalma stratejilerini başarılı bir şekilde çiftlik hayvanları üzerinden sağladıklarını göstermektedir.

Her ne kadar Derekutuğun ve Boğazköy yerleşimleri birbirlerine bölgesel ve dönemsel olarak yakın olsa da, kırmızı et kazanımı ile ilgili stratejileri yalnızca temelde benzerlik gösterir; o da çiftlik hayvanlarının tür listesidir. Yerleşim yerlerinden aynı evcil hayvanlar tanımlanmıştır. Bunlar dönemsel ve bölgesel olarak aslında çok şaşırtıc1 sonuç vermemektedir. Fakat bu evcil hayvanların sürülerdeki dağılımı ve insanların kırmızı et kazanımına katkı payları bu yerleşim yerlerinde kesin zıtlıklar göstermektedir.

Sürülerdeki dağılımlarına bakıldığında üç büyük 
farklılık hemen göze çarpmaktadır. Boğazköy'de Derekutuğun'a göre üç kat fazla keçi beslenirken, domuz Derekutuğun'da Boğazköy'e göre 3,75 kat fazla tutulmuştur. Diğer en büyük fark ise kendini sığır sürülerinde gösterir. Boğazköy'de beslenen sığırlar Derekutuğun'dakilere oranla iki kat fazladır. Koyunların sürülerdeki adet olarak dağılımı ise hemen hemen aynidır.

İlk Tunç Çağ'1 yerleşimlerinde beslenen hayvan türleri ve bunların adets olarak dağılımları aslında "en" temel olarak iki noktaya dayanmalıdır/dayandırılmadır: Birincisi coğrafî durum ve onun sağladığı şartlar, ikincisi de yerleşim yerinin yaşamsal ve maddî ekonomisinin devamlılığını sağlayacak en uygun besicilik stratejisi. Sürülerin dağılımına bakılınca koyun besiciliğinin her iki yerleşimde de önemi yadsınamaz. Derekutuğun'da koyunu domuz ve sığır takip ederken Boğazköy'de de koyunu sığır ve keçi takip etmektedir. Bu durumda sürüler içindeki yüzdesel değişimleri "ekonomik" sebeplere bağlayabiliriz; çünkü bu iki yerleşim yerinin coğrafyası temelde pek de farkl111k göstermemektedir

$\mathrm{Bu}$ çalısmanın asıl konusu olan "kırmızı et ile beslenme alışkanlıklarına" gelecek olursak, aynı bölgede bulunan iki yerleşimin sonuçları yine birbirinden çok farklı bir tablo yansıtmaktadır. Derekutuğun'da evcil küçükbaş geviş getirenler, sığır ve domuz eti yerleşimde eşit yoğunlukta tüketilirken, Boğazköy'de et ihtiyacinın \% 70'i sığırdan, kalan \%30'un büyük kısmı evcil küçükbaş geviş getirenlerden ve yalnızca $\sim \% 8$ 'i domuzdan karşılanmaktadır. Bu et tüketimi stratejisi de aslında yerleşiminin ekonomik işleyişi, nüfusu, yerleşimin yayalım alanı ve belki coğrafyası ile de alakalı olmalıdır.

Derekutuğun'da maden işçilerinin odaklandığ 1 ekonomik getiri bakır cevherinin çıkarılması ve işlenmesidir. Ana geçim kaynağ yüzden hayvancilık ikinci plandadır. Bu işçi topluluğunun ihtiyaç duydukları yüksek miktardaki proteini alabilmeleri için yoğun şekilde domuz beslemelerine ve etini tüketmelerine, domuzun diğer türlere göre sahip olduğu biyolojik avantajları sebep olmuştur. Bunlar domuzların erken olgunlaşması, yem seçimi yapmaması, bir kerede birçok sayıda yavrulayabilmesi ve senede iki kere yavrulamasidir.

Yerleşim yerlerinin nüfusları da tür tercihlerinde önemli roller oynamış olabilir. Boğazköy'de yoğun olan nüfus sığır kesilmesini daha makul duruma getirmiş olabilir. Bir sığır kesildiği zaman ortaya çıkacak eti bozulmadan büyük aileler arasında paylaşmak veya takas yolu ile ekonomiye sokmak daha mantiklı olabilecekken, Derekutuğun'daki nüfus daha az olduğundan kesim sonrası daha az et miktarını hızlı tüketilebilecek evcil hayvanı seçmiş olmalıdırlar.

Sığırlar grup hâlinde kontrolü ve yönlendirilmesi daha kolay sürü hayvanlarıdır ve bu durum hayvan hırsızları, hatta yağmacılar için sığırları daha değerli bir mal grubuna sokmaktadır (yerleşmede bir savunma sistemi de henüz tespit edilmemiştir).

Yerleşiminin etrafindaki coğrafî etkenlere bakıldığında Derekutuğun'un etrafı daha dik ve keskin yapıya sahipken, Boğazköy'ün çevresi sığırların otlaması için daha çok düz alanlar sağlamaktadır. Bölgedeki Kuruçay, Tepekutuğun, Derekutuğun, Beydili, Belören, Bayat ve Pancarlık gibi bazı günümüz kasabalarını göz önünde bulundurursak -kabaca Batı'dan Doğu'ya hafif bir yay çizersek, bu yayın güneyinde sığırların otlaması için gerekli coğrafi koşulları sağlamaktadır. $\mathrm{Bu}$ da bize Derekutuğun çiftçilerinin az sığır beslemelerinin sebebinin coğrafî koşullara pek dayandırılamayacağını göstermektedir.

Derekutuğun'daki madenciler, anlaşılan, sahip oldukları enerjinin çoğunu bakır madenini çıkarıp onu işlemeye odaklamıştır. Madenciler, domuz besiciliği ile ihtiyaçları olan yüksek düzeydeki proteine hızlı ve taze olarak ulaşmışlardır. Derekutuğun'da tanımlanmış evcil türlerin eşit şekilde et kazanımında bulunması aynı zamanda da yerleşim yerinde aslında çok bilinçli bir besicilik yapıldığını göstermektedir ve herhangi bir türe gelebilecek olası hastalık sonrası risk eşit şekilde dağıtılmıştır. Koyunun ilk etapta eti ve aynı zamanda da ikincil ürünleri için de beslendiği düşünülmelidir; fakat bu madenci yerleşiminin birincil vazifesinin maden işletmeciliği olduğu düşünülürse, ikincil ürünlerin üretimi için az vakit kalıyor olmalıydı. Eşek/katır ise bize Derekutuğun'un ticaret ağ1 içinde hammadde kazanımı için önemli bir başlangıç noktasında olduğunu göstermektedir.

\section{Teşekkür}

Derekutuğun yerleşim yerinin hayvan kemiklerini çalışılması için beni ve ekibimi davet eden Prof. Dr. Ünsal Yalçın'a çok teşekkür ederim. Bize her konuda yardımc1 olan Çorum Müzesi Müdürü Sayın Metin Çakar'a ve çalışma arkadaşlarına da ayrıca teşekkür ederim.

\section{Kaynakça}

Fisher, J. W. (1995). Bone surface modifications in zooarchaeology. Journal of Archaeological Method and Theory, 2(1), 7-68. DOI: 10.1007/BF02228434

Gündem, C. Y. (2010). Animal Based Economy in Troia and the Troas during The Maritime Troia Culture (c. 3000-2200 BC.) and a General Summary for West Anatolia (Yayımlanmamış Doktora Tezi). Eberhard Karls Universität Tübingen, Almanya.

Gündem, C. Y. (2015). Arkeozooloji Biliminin Arkeoloji Dünyasındaki Önemi Bölüm I. Batman Üniversitesi Yaşam Bilimleri Dergisi, 5(1), 125 -138.

Hillson, S. (1986). Teeth. Cambridge: Cambridge University Press. 
Hillson, S. (1992). Mammal Bones and Teeth: an Introductory Guide to Methods of Identification. London: Institute of Archaeology, University College London.

Kubasiewicz, M. (1956). O metodyce badan wykopaliskowich szczatkow Kostynch zwierzecych [Hayvan kalıntılarının araştırılması metodolojisi üzerine]. Materialy ZachodnioPomorskie, 2, 235-244.

O'Connor, T. P. (2000). The Archaeology of Animal Bones. Stroud: Sutton Publishing.

Payne, S. (1973). Kill-off Patterns in Sheep and Goats: The Mandibles from Aşvan Kale. Anatolian Studies, 23, 281-303. DOI: $\underline{10.2307 / 3642547}$

Reitz, E., ve Wing, E. (2008). Zooarchaeology (Cambridge Manuals in Archaeology). Cambridge: Cambridge University Press. DOI: 10.1017/CBO9780511841354

Schmid, E. (1972). Atlas of Animal Bones. Amsterdam: Elsevier.

Uerpmann, H. P. (1971). Studien über frühe Tierknochenfunde von der Iberischen Halbinsel. Vol. 2: Die Tierknochenfunde aus der TalayotSiedlung von S'Illot (San Lorenzo/Mallorca). München: Universität München.

Uerpmann, H. P. (1973). Animal bone finds and economic archaeology: A critical study of 'osteo-archaeological' method. World Archaeology, 4(3), 307-322. DOI: $\underline{10.1080 / 00438243.1973 .9979541}$

von den Driesch, A. (1976). A Guide to The Measurement of Animal Bones From Archaeological Sites. Cambridge: Peabody Museum of Archaeology and Ethnology, Harvard University.

von den Driesch, A. ve Pöllath N. (2004). Vor- und frügeschichtliche Nutztierhaltung und Jagd auf Büyükkaya in BoğazköyHattusa, Zentralanatolien [Orta Anadolu BoğazköyHattuşa'nın Prehistorya Protohistoryasında Çiftlik Hayvanı Bakımı ve Av1] . Mainz am Rhein: P. von Zabern.

Yalçın, Ü., ve İpek, Ö. (2011). Derekutuğun Tarih Öncesi Maden Galerileri. 1. Corum Ką̧ ve Araştırmalar Semposyumu içinde, (s. 65-78). Çorum: T.C. Çorum Valiliği.

Yalçın, Ü., ve İpek, Ö. (2012). Derekutuğun Tarih Öncesi Maden Galerileri. 2. Corum Ką̧ ve Arastırmalar Semposyumu içinde, (s. 11-31). Çorum: T.C. Çorum Valiliği.

Yalçın, Ü., Yalçın, H. G., Ekmen, H., ve İpek, Ö. (2018). Derekutuğun Eski Maden işletmeleri ve Madenci Yerleşmesi 2016 Çalışmaları. Ką̧ Sonuçlar Toplantısı, 39(3), 573-596.

Yalçın, Ü., Yalçın, H. G., Maass, A., ve İpek, Ö. (2015). Derekutuğun Tarih Öncesi Bakır İşletmeleri. Ü. Yalçın ve H.-D. Bienert (Ed.) içinde, Kültürlerin Köprü̈ü Anadolu: Türk-Alman Eskiçağg Bilimlerinde Güncel Bilimsel Araştırmalar ve Yeni Bakus Açlar Uluslararası Sempozyumu Kitabı (s. 147-184). Bonn: Deutsches Bergbau-Museum. 